\title{
FÓRUM
}

\section{Egy kulcs az önálló életvitelhez - A támogatott lakhatás helye és szerepe a magyarországi szociá- lis szolgáltatások rendszerében}

A magyarországi szociális szolgáltatások rendszerében a támogatott lakhatás (továbbiakban: TL) szabályozása teljesen új utakat nyitott. Új elvek és értékek jelentek meg a müködés, müködtetés hátterében. A nemzetközi kötelezettségekből fakadó, hazai stratégiákra is épülö, új szolgáltatási elemként a modell bevezetése az újszerü, innovatív gondolkodást is meghozta a szociális szakma szemében. A TL szabályozása a merev (otthonközeli-bentlakásos ellátás dichotómiára vonatkozó) meghatározás helyett egy teljesen új megközelítést, a személyközpontú, szükségletalapú, szolgáltatási elemekre építő logikai struktúrát hozta színre a szociális szolgáltatások esetében.

A TL középpontjában az önálló életvitel áll: személyre szabottan megvalósítható, önálló életvitelt elősegítő, fenntartható szolgáltatást tartalmaz. Másként fogalmazva: a szociális alapszolgáltatások együttmüködő, összeszervezett igénybevételének lehetőségét és az adott személy lakhatását kell biztosítania a TL megszervezését, biztosítását vállaló fenntartónak, intézménynek, olyan módon, hogy azok egyénre szabott kombinációját kell kialakítani, amely döntően új megközelítést kiván meg valamennyi érintettől: fenntartóktól, intézmény- és szolgáltatásvezetőktől, dolgozóktól, de még az engedélyező és ellenőrző hatóságok munkatársaitól is.

A TL szolgáltatási forma elterjedtsége területileg nagyon változó képet nyújt. Elérhetősége és igénybevétele ma még erősen korlátozott Magyarországon. Javulásra ad reményt, hogy a TL fenntartói körében rugalmasabb, civil és egyházi fenntartók vesznek részt.

Fő feladatnak tűnik, hogy a TL bevezetése és elterjedése által elindult paradigmaváltás, szemléletmódosulás elönyeit meg tudjuk őrizni, $s$ továbbra is valódi innovációként tekintve a TL-re. A stabil jövőkép érdekében fontos szakmai vitákat kellene még lefolytatni, melyek őszintén végigveszik és végiggondolják a TL jövőbeni helyét és szerepét a hazai ellátásokban. Kulcsszavak: szociális szolgáltatás, szociális intézmény, támogatott lakhatás, fogyatékos személyek, pszichiátriai betegek, szenvedélybetegek 


\section{BeVEzetés}

A magyarországi szociális szolgáltatások rendszerét a mai napig a szociális igazgatásról és szociális ellátásokról szóló 1993. évi III. törvény (Sztv.) közel harminc éve megalkotott hierarchiája és definíciós kényszere határozza meg.

Ennek a jogszabálynak a keretei és a benne tükröződő alapelvek mára messze kerültek az életszerűségtöl, valamint még messzebb a nemzetközi szabályozásoktól. Szükséges lenne a mai értékek és alapelvek mentén újragondolni kereteit és teljes rendszerét, mert nehéz az újszerủ működésű elemeket beleilleszteni. A támogatott lakhatás (továbbiakban: TL) formája is ezek közé tartozik.

Ebben a - számos szakértő* (*Pl. Czibere Károly volt államtitkár előadásai, szakértői

megszólalásai [http://www.macsgyoe.hu/downloads/rendezvenyek/czibere2012.pdf/ »Letöltés ideje: 2020.január05.«], és másszakértők [pl. http://www.esely.org/kiadvanyok/2012_3/2.szekcio.pdf/ »Letöltés ideje: 2020. január 05.«] vagy http://www.3sz.hu/sites/default/ files/uploaded/pelle_jozsef_ __szocialis_intezmenyekstrukturalis_problemai.pdf/ [Letöltés ideje: 2020. január 05.]) Szerint idejétmúlt - szabályozási nomenklatúrában sajátos jelentése van az „alap” és a „szakosított” kifejezéseknek. A szociális szolgáltatási struktúrában az „alap” szolgáltatási alrendszer mindig az otthonközeli, bentlakást nem biztosító ellátásokat jelenti, míg a szakosított formák mindig valamilyen típusú lakhatás megvalósítását foglalják magukban.

Ezen szolgáltatásokat végigtekintve azonban láthatjuk, hogy a szolgáltatások keretein belül ténylegesen megvalósuló tevékenységek (szolgáltatási elemek) nagyon sok esetben átfedéseket tartalmaznak. Ezen egyezőségek és a bizonytalan körvonalú lehatárolások miatt nemcsak a szakmán kívülállók (laikusok), hanem a szolgáltatásokat szervezők, végzők körében is sokszor összemosódnak a határok az egyes elemek között. Ez nem segíti sem a szakmai, sem a pénzügyi fegyelem betartását és betartatását. Nagyobb gond, hogy az igénybevevők, rászorulók körében sem világosak a szolgáltatási tartalmak és keretek.

A TL ebben az idejétmúlt - elhatároló, rugalmatlan és sokszor életszerütlen - logikai felosztás kereteit feszegetve került 2012-ben az említett jogszabályba (Sztv.). Nemzetközi kötelezettségekböl* (*UN Convention on the Rights of Persons with Disabilities [CRPD], a magyar Országgyülés által a 2007. évi XCIl. törvénnyel kihirdetett egyezmény, melynek magyar nyelvü, értelmező fordításának elérése: https://www.un.org/disabilities/documents/ nat//hungary-ez.pdf/ [Letöltés ideje: 2020. január 11.]) fakadó, hazai stratégiára* (*UN Convention on the Rights of Persons with Disabilities [CRPD], a magyar Országgyülés által a 2007. évi XCII. törvénnyel kihirdetett egyezmény, melynek magyar nyelvü, értelmező fordításának elérése: https://www.un.org/disabilities/documents/natl/hungary-ez.pdf/ [Letöltés ideje: 2020. január 11.]) is épülö, új szolgáltatási elemként a modell bevezetése az újszerü, innovatív gondolkodás reményét is jelentette a szociális szakma jelentős részének a szemében. A TL szabályozása a merev (otthonközeli-bentlakásos ellátás dichotómiára vonatkozó) meghatározás helyett egy teljesen új megközelítést, a személyközpontú, szükségletalapú, szolgáltatási elemekre építő logikai struktúrát hozta színre a szociális szolgáltatások esetében. 


\section{A támogatott lakHatás Helye A SZOCIÁLIS SZOLGÁLTATÁSI RENDSZER- BEN}

A Sztv. alapvető, logikailag még jól értelmezhető rendszerében a TL szolgáltatási/ intézményi formaként egy új kategóriát nyitott a szabályozásban.

Ennek áttekintéséhez érdemes végigtekinteni a meglévő szolgáltatási rendszert. Az ábra a Sztv. 66-85/A. §-aiban meghatározott ellátási formákat rendezi típus és (eltérő színmélységgel jelölve) célcsoportok szerint.

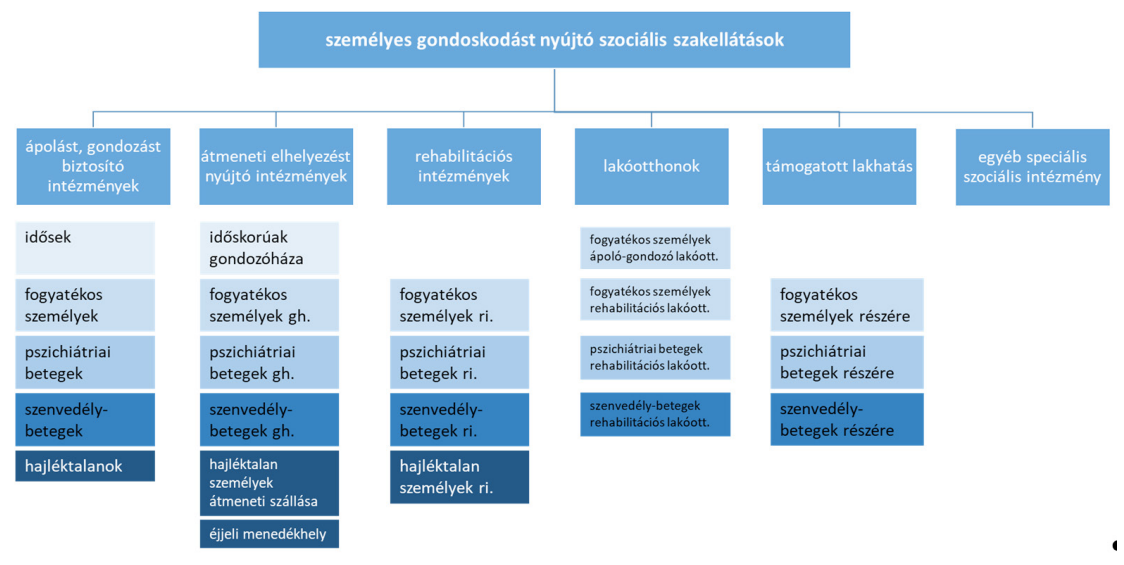

1. ábra: Személyes gondoskodást nyújtó szociális szakellátások

A szabályozás az első négy csoportban (ápolást, gondozást biztosító intézmények; átmeneti elhelyezést biztosító intézmények; rehabilitációs intézmények, nagyobbrészt a lakóotthonok tekintetében is) intézményi müködési kereteket rögzít. Leírja azt, hogy - minden ellátott számára, a megfelelő célcsoport specifikus eltérései mellett - milyen fizikai környezetben, milyen szakmai tartalmakkal és megvalósuló tevékenységekkel szükséges az intézményeknek müködnie.

A TL szabályozása azonban ettől lényegesen eltér.* ( ${ }^{*}$ Homicskó Á. O. [2018]. Szociális jog II. - Tananyag a társadalombiztositási és szociális ellátások megismeréséhez. Második, átdolgozott kiadás. Budapest: Patrocinium.) A szolgáltatás középpontjában az önálló életvitel áll: a személyre szabottan megvalósítható, önálló életvitel elősegítését és fenntartását kell megvalósítania a szolgáltatásnak. Az önálló életvitel azonban eltérő segítséget igényel egyénenként és érintettségenként (fogyatékos, pszichiátriai beteg és szenvedélybeteg személyek helyzetétől, életkorától, állapotától és betegségeitől is függően). Ezt az eltérő szükségletet eltérő módon lehet csak - optimálisan - kielégíteni, ezért a szabályozás önálló elemekre bontva tartalmazza a biztosítandó tevékenységeket:

- lakhatás,

- támogató technikák (mentálhigiénés, életviteli és egyéb kérdésekben),

- kísérés (szükség szerint a közlekedést, szállítást is megoldva),

- étkezés (szükség szerinti diétával is), 
- ápolás-gondozás (egészségügyi állapot függvényében),

- fejlesztés (meglévő, esetleg részképességek alapján),

- „társadalmi életben való részvétel” biztosítása.

Az egységes elnevezésű szolgáltatás elemekre bontása már önmagában is újszerü, hiszen a látszólag „egységes” tartalmú bentlakásos ellátások esetében ez ma még nem valósul meg. Ez a - nevezzük így - „szétszálazós logika” az egyik legfontosabb áttörés a szolgáltatási monolitok világában.

A szabályozás egyik legérdekesebb sajátosságát az adja, hogy a fenti felsorolás valamennyi eleme (a lakhatás kivételével) megtalálható a szociális alapszolgáltatások körében is. * (* Uo. 184-191p.) Lényegében tehát a szociális alapszolgáltatások együttműködő, összeszervezett igénybevételének lehetőségét és az adott személy lakhatását kell biztosítania a TL megszervezését, biztosítását vállaló fenntartónak. Ráadásul oly módon, hogy azok egyénre szabott kombinációját kell kialakítani, amely döntően új megközelítést kíván meg valamennyi érintettöl: fenntartóktól, intézmény- és szolgáltatásvezetőktől, dolgozóktól, de még az engedélyező és ellenörző hatóságok munkatársaitól is.

\section{A TÁMOGATOTT LAKHATÁS SZOLGÁLTA- TÁS KIÉPÜLTSÉGE}

Az elmúlt évek adatai alapján látható, hogy alig változó volumennel, mindösszesen 92.000 fö él Magyarországon szociális szolgáltatást nyújtó intézményi környezetben, bentlakásos otthonokban. Ezen adaton belül - szintén csekély csökkenést mutatva - a fogyatékossággal élő személyek száma hozzávetőleg 15.000 fő, a pszichiátriai betegek (pszichoszociális fogyatékossággal élők) száma 8.400 fö, míg a szenvedélybetegek (föként alkoholbetegek) száma 2.000 fő volt.

Mindezen adatokhoz képest a fenti három célcsoportra vonatkozóan, mindöszszesen 1.626 féröhelyen* (*Forrás valamennyi alapadathoz: $\mathrm{KSH}$; elérhetőség: https://www. ksh.hu/docs/hun/xstadat/xstadat_eves /i_fsi001.html\#/ [Letöltés ideje: 2020. január 12.]) müködött jelen írás elkészültekor TL az országban. (Érdekes továbbá, hogy ez csupán kicsivel kevesebb, mint a kb. 1.800 fő részére szolgáltató lakóotthonok kapacitása.)

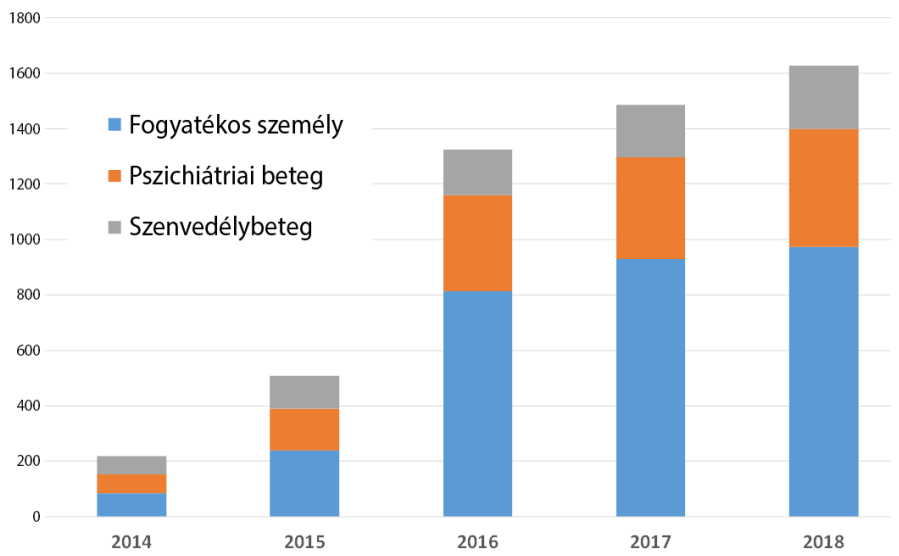

2. ábra: Az összkapacitás dinamikus emelkedése (Forrás: KSH és saját számítások) 
A célcsoportok szerinti eloszlás a TL adatokban is hozzávetőlegesen tükrözi a tartós bentlakásos intézményben élők arányait, s láthatóan az értelmi fogyatékossággal élő személyek teszik ki a TL igénybevevők $60 \%$-át.

A TL kapacitások területi eloszlása jelenleg óriási különbségeket mutat. Míg a szociális szolgáltatások kapacitás eloszlásában is látunk egy kelet-nyugati tengelyt hazánkon belül (a keleti megyékben és Budapesten lényegesen magasabb a szolgáltatási kapacitás, mint az országos átlag), addig ez a TL esetében még erősebben látszódik. Olyan szélsőséges adatokat találhatunk, mint például Szabolcs-Szatmár-Bereg megyében 278 fö élhet TL szolgáltatás keretei között, míg Vas megye vagy Győr-Moson-Sopron megye érintettjei egyetlen férőhelyet sem érhetnek el a megyében. A 2018-as statisztikai adatok szerint nulla (!) féröhely az elérhető kapacitás pl. ebben a két megyében. ( ${ }^{*}$ Forrás: KSH STADAT, 2020.)

Elemezve a helyzetet - értelmezési lehetőségként - adódik a magyarázat a területileg nem arányos innovációra, hogy a számokat a kitagolási (intézménytelenítési) programba* ("Andráczi-Tóth V., Bódy É. - Csicsely Á., \& Nyitrai I. [2011]. Az intézménytelenítés kapujában -A Pixelből kép válhat? Esély, 22(4), 35-57.) bevont állami intézmények földrajzi elhelyezkedése is befolyásolhatja. Ez vélhetöleg oka lehet nagyobb eltérésnek, de a TL teljes hiánya valószínüleg mást is mutathat, ez azonban további kutatásokat, vizsgálódást igényelne.

Érdekes még röviden elemezni, hogy a TL milyen fenntartói háttérrel valósul meg. Alapul véve azt a közkeletű megfigyelést, szervezetszociológiai alaptézist, hogy a kisebb szervezetek rugalmasabb és mozgékonyabb változásokra, fejlődésre képesek, fejlesztési potenciálban gazdagabbak, innovatívabbak, akkor félig már magyarázatot is kapunk a jelenlegi helyzetre.

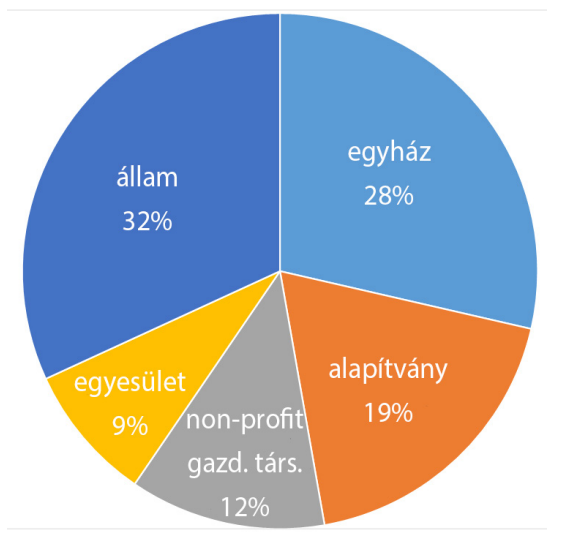

3. ábra: A támogatott lakhatási féröhelyek fenntartói háttere (Forrás: KSH és saját számítások)

Az összkép alapján „egészséges” szerkezetben alakul a kapacitások fenntartói háttere: egyharmad-egyharmad arányban vesz benne részt az állam, az egyházak és a civil szféra szereplői. Az egyesületi és alapítványi formában létrejött TL kapacitások kezdeményezői és fenntartói mögött nagyon sokszor érintetti csoportok (többnyire szülök közösségei) állnak. Ez a tendencia már az 1990-es években, az ún. lakóotthoni fejlesztések idején is tapasztalható volt. 
Szociális ágazati tények alapján látható az is, hogy nem a nagy, történelmi egyházak, komoly hierarchiával működő fenntartói szervezetek, hanem a helyi, gyülekezeti szintű és többször máltai hátterü* ( ${ }^{*}$ A Máltai Szeretetszolgálat által fenntartott.) egyházi szervezetek alakítottak ki és müködtetnek TL-t. Ezek és a civil fenntartású TL-ek (egyelöre) laza hálózati együttmüködése éppen a 2010-es évek végén kezdett el müködni.* ("A keretet is egyházi szereplő adja, a hálózat gondozása a Baptista Egyházi Szociális Módszertani Központ támogatásával valósul meg [forrás: Alap Vető, 2(23)].)

\section{A TÁMOGATOTT LAKHATÁS SZABÁLYOZÁSI SAJÁTOSSÁGAI}

A TL szabályozási beágyazottságának bemutatásához szükséges megismerni nemcsak a szociális szolgáltatások szabályozásáért felelős joganyag vonatkozó részeit, hanem a fogyatékos személyek jogairól és esélyegyenlőségük biztosításáról szóló 1998. évi XXVI. törvény (Fot.) vonatkozó részeit is.

\subsection{A támogatott lakhatás szabályozása a Fot. keretei között}

A Fot. nem csak általánosságban, és nem csupán a fogyatékossággal élő személyek jogai oldaláról fogalmaz meg kereteket, hanem konkrét szolgáltatásokat, illetve azokra való hivatkozásokat is tartalmaz. (Ilyen például a támogató szolgálat, mint speciális szociális alapszolgáltatás.)

A Fot. alapján a fogyatékossággal élő személyek választási lehetőséggel élhetnek a családi, lakóotthoni vagy intézményi lakhatási forma között. A törvény nem tartalmaz rendelkezést a kapcsolódó szolgáltatásokról, például az ún. személyi segítő szolgálat* (*Ld. a kérdés egyes dilemmáiról és a rendszer anomáliáiról bővebben: Sándor A., \& Kunt Zs. [2020]. „A »gondozás« túlélést biztosít számunkra, a »személyi asszisztencia» életet" - A Személyi Asszisztencia Szolgáltatás szakirodalmi hátterének elemző áttekintése. Szociálpolitikai Szemle, 6(1), 5-26.) igénybevételéhez való jogról, mely számos országban lehetővé teszi az önálló életvitelt a fogyatékossággal élő személyek számára. ${ }^{*}$ (*Gradwoh Csilla [2014]. A fogyatékossággal élők közösségben való élethez fűződő jogáról. De iurisprudentia et iure publico, 8(3), 1-13.)

A lakhatással kapcsolatban azonban csak egy konkrétum szerepel a törvényben, mégpedig az értelmező rendelkezések között:

- Fot. 4. § e) lakóotthon: a fogyatékos személy önálló életvitelét elősegítő, kisközösséget befogadó lakhatási forma.* (*Megállapította: az eredeti jogszabály, bő két évtizede.)

Megjelenik tehát az önálló életvitel, de csak a lakóotthoni ellátási forma bemutatásakor. A lakóotthon azonban - ahogyan azt később részletesebben bemutatom - egy bentlakásos ellátási forma „családiasabb méretü” változata, s valójában a „nagy intézményekhez” nagyon hasonló formájú, szabályozású változata a bentlakást nyújtó szociális szolgáltatásoknak.

A lakhatással kapcsolatos újabb - és egyben utolsó - pont a törvényben éppen 52 az önállóság, az önálló életvitel és az inklúzió kapcsán jelenik meg. 
- $\quad$ 17. § (1) A fogyatékos személynek joga van a fogyatékosságának, személyes körülményeinek megfelelő - családi, lakóotthoni, intézményi - lakhatási forma megválasztásához. ${ }^{*}$ * Megállapította: 2010. évi XXXIX. törvény 30. §. Hatályos: 2010. III. 31-töl.)

Ahogy látható, ez nem a szolgáltatási tartalom oldaláról, hanem a fogyatékos személy önálló döntéshozatala, jogérvényesülése oldaláról, a lakhatási körülmények megválasztásának szabadsága kapcsán rögzít jogokat.

Összegezve, a TL még csak említésre sem kerül a Fot.-ban. (A TL szabályozása 12 évvel a Fot. elfogadása után született meg.) Ez azonban leginkább a Fot. felülvizsgálatának és valós, szabályozási rendszerben elfoglalt helye meghatározásának kérdéseit veti fel, mely nem tárgya jelen írásnak. A Fot. felülvizsgálata pedig talán égetőbb lenne, mint más, vonatkozó szabályozóké.

\subsection{Sajátosságok a TL-szabályozásban}

A szociális törvény (Sztv.) a TL-t - alapbesorolás szintjén legalábbis - kiveszi a tartós bentlakásos intézményi (intézeti) kategóriából:

- Sztv. 57. § (2) A személyes gondoskodás keretébe tartozó szakosított ellátást

a) az ápolást, gondozást nyújtó intézmény,

b) a rehabilitációs intézmény,

c) a lakóotthon (a továbbiakban a) és c) pont együtt: tartós bentlakásos intézmény),

d) az átmeneti elhelyezést nyújtó intézmény [a továbbiakban a) és d) pont együtt: bentlakásos intézmény],

e) a támogatott lakhatás, ${ }^{*}$ ( ${ }^{*}$ Megállapította: 2012. évi CXVIII. törvény 5. §. Hatályos: 2013. I. 1-től.)

f) az egyéb speciális szociális intézmény* ( ${ }^{\star}$ Apró érdekesség, de a rendszer szabályozási útvesztőjéről, dzsungeljéről sokat elárul, hogy nyolc esztendős, központi közigazgatásban töltött, több évtizedes szociális szférában szerzett tapasztalat alatt sem derült ki számomra [sem], mit is jelent az egyéb speciális szociális intézmény értelmezési kategória. Vélhetően vagy egy teljesen kiürült, esetleg már eleve gumiszabályozást megengedő kategóriaként kerülhetett a szabályozásba.) nyújtja. ( ${ }^{*}$ Kiemelések a szerzőtöl.)

A törvényi szinten megvalósuló szabályozás rendkívül részletesen magában foglalja azt is, hogy a sajátos, korábbi szolgáltatási értelmezésekbe közvetlenül nem illeszthető új forma milyen tartalmi követelményeket hordoz. A részletes szabályozás törvénybe foglalása - tapasztalatom szerint - mindig egyfajta „védelem” vagy prevenció részét képezi: a szabályozást alkotó a szabályok könnyü változtathatóságának elkerülése érdekében illeszti/illesztheti az adott pontokat - országgyülési elfogadást igénylö - jogszabályba.

Látható ez a lenti részletszabályok kapcsán is, ahol a TL önálló fejezetet is kapott.

- Sztv. 75. § A támogatott lakhatás a fogyatékos személyek, a pszichiátriai betegek - ide nem értve a demens személyeket - és a szenvedélybetegek részére biztosított ellátás, amely az életkornak, egészségi állapotnak és önellátási képességnek megfelelően, az ellátott önálló életvitelének fenntartá- 
sa, illetve elősegítése érdekében biztosítja* ( ${ }^{*}$ Megállapította: 2012. évi CXVIII. törvény 7. §. Hatályos: 2013. I. 1-töl.)

a) a lakhatási szolgáltatást,

b) az önálló életvitel fenntartása, segítése érdekében a mentálhigiénés, szociális munka körébe tartozó és egyéb támogató technikák alkalmazásával végzett esetvitelt,

c) a közszolgáltatások és a társadalmi életben való részvételt segítő más szolgáltatások igénybevételében való segítségnyújtást,

d) az ellátott komplex szükségletfelmérése alapján, erre vonatkozó igény esetén

da) a felügyeletet,

db) az étkeztetést,

dc) a gondozást,

dd) a készségfejlesztést,

de) a tanácsadást,

df) a pedagógiai segítségnyújtást,

dg) a gyógypedagógiai segítségnyújtást,

dh) a szállitást,

di) a háztartási vagy háztartást pótló segítségnyújtást. * ("Kiemelés a szerzőtöl.)

Támogatott lakhatásban az (1) bekezdés szerinti személy gyermeke is ellátható.

(2) Az (1) bekezdés $d$ ) pontja szerinti szolgáltatási elemeket* ("Kiemelés a szerzőtől.) a fenntartó

a) a (3) bekezdés szerinti szociális szolgáltatást nyújtó szolgáltatóval, intézménnyel a szolgáltatási elem nyújtására kötött megállapodás útján,

b) a támogatott lakhatás részeként, a szakmai létszám és tárgyi feltételek teljesítésével,

c) a szintén saját fenntartásában álló, (3) bekezdés szerinti szociális szolgáltatások útján, vagy

d) az (1) bekezdés d) pontja szerinti szolgáltatási elemekre kiterjedő tevékenységi köre szerinti müködési feltételeknek megfelelő szervezet útján, az intézményi szolgáltatások intézményen kívüli szervezet által történő ellátásának szabályai szerint biztosíthatja.

A fenti szabályozásban tehát két, egyenként is teljesen innovatív elem jelenik meg.

Egyrészt az addig - viszonylag - egységes, „tömbszerū” szolgáltatási kategóriák helyett a sokkal pontosabban megfogalmazható, átlátható kategóriákat választja irányadónak. Ezek az ún. szolgáltatási elemek, amelyek olyan alapvető tevékenységeket tartalmaznak, amelyek az érintett személy adott szükségleteihez jól illeszthetőek.

Ezzel megvalósul a személyre szabott, az egyén meglévő képességeire épülni tudó, önálló életvitelt kialakítani és fenntartani képes segítő tevékenységi kör. (A jelen tanulmányban részletesen nem elemzett kiváltási, kitagolási koncepciók ezt a tevékenységi sort az egyént segítő szolgáltatói gyürüként fogalmazzák meg.)

Másrészt - és ez kisebb figyelmet szokott kapni - megjelenik a szociális szolgáltatók közötti együttműködés lehetőségének (és sokszor életszerű kényszerének) 
kérdése is. Ugyanis a TL fenntartójának nem kell (sokszor nem is lehet, nem is tudhat) minden elemet önállóan biztosítania, hanem - ahogyan a többségi helyzetekben, mindennapi életvitelünkben is tesszük - a szolgáltatási lehetőségekből kell kialakítani azt az egyénre szabott portfóliót, amely a legjobban szolgálja az önálló életvitel megtartását az érintett TL-igénybevevőnél. A szabályozás ehhez ráadásul még egészen pontos „útmutatót” is ad.

- Sztv. 75. § (3) A (2) bekezdés a) és c) pontja szerinti esetben

a) a felügyeletet jelzőrendszeres házi segítségnyújtás, támogató szolgáltatás vagy nappali ellátás,

b) az étkeztetést étkeztetés vagy nappali ellátás,

c) a gondozást házi segítségnyújtás, közösségi alapellátás, támogató szolgáltatás vagy nappali ellátás,

d) a készségfejlesztést közösségi alapellátás, támogató szolgáltatás vagy nappali ellátás,

e) a tanácsadást közösségi alapellátás, támogató szolgáltatás, nappali ellátás vagy család- és gyermekjóléti szolgáltatás,

f) a pedagógiai segítségnyújtást támogató szolgáltatás, nappali ellátás, család- és gyermekjóléti szolgáltatás vagy gyermekek napközbeni ellátása,

g) a gyógypedagógiai segítségnyújtást támogató szolgáltatás, nappali ellátás vagy család- és gyermekjóléti szolgáltatás,

h) a szállítást támogató szolgáltatás vagy falugondnoki és tanyagondnoki szolgáltatás,

i) a háztartási vagy háztartást pótló segítségnyújtást házi segítségnyújtás, nappali ellátás vagy támogató szolgáltatás nyújtására a szolgáltatói nyilvántartásba bejegyzés alapján jogosult szervezet útján lehet biztosítani.

Véleményem szerint ez a szabályozási mátrix már túlzottan aprólékos, de a szabályt megfogalmazók abból a - sajnos teljesen igazolt - helyzetből indultak ki, amely szerint a szociális szolgáltatásokat fenntartó, irányító személyek nem ismerik, sokszor nem is látják át a szociális szolgáltatások egészét. Az ellátotti jogok érvényesítése és az ellátási biztonság érdekében így egy nagyon pontos, szinte mindenre kiterjedő „útvonaltervet” fogalmaztak meg a szabályozásért felelős szakemberek a törvényben.

Fontos még kiemelni, hogy a TL-szabályozás egyik sarkalatos pontja a lakhatási szolgáltatás (szolgáltatási elem) mérete, vagyis a használt lakás/ház méretének, nagyságának, befogadóképességének a kérdése. Nagyon sokan a teljes intézménytelenítési folyamat sarokkövének tekintik a minél kisebb - lehetőleg egyszemélyes lakhatást biztosító - formák meglétét vagy hiányát mind Magyarországon* ( ${ }^{*}$ h hazai gyakorlat legerősebb - politikai elfogultságoktól sem mentes - szereplöjének 2019-es véleménye: https://tasz.hu/cikkek/aggasztoelojelekakitagolasjovojerol/ [Letöltés ideje: 2020. január 14.]), mind Európában. ${ }^{*}$ ( $F$ rom institutions to community living for persons with disabilities: perspectives from the ground, forrás: https://fra.europa.eu/en/publication/2018/independent-living-reality/ [Letöltés ideje: 2020. január 14.])

A pontosság kedvéért a törvény tehát ezeket a paramétereket is szabatosan rögzíti:

- Sztv. 75. § (5) A lakhatási szolgáltatás

a) legfeljebb hat fö számára kialakított lakásban vagy házban, vagy 
b) hét-tizenkét fő számára kialakított lakásban vagy házban, vagy

c) legfeljebb ötven fő elhelyezésére szolgáló lakások, épületek együttesében biztosítható.

A gyakorlat nyelvén tehát ez azt jelenti, hogy a TL lakhatási eleme kisebb-nagyobb lakásban, házban vagy társasház/lakópark jellegü épületekben oldható meg. (Érdekesség: a népesség nem intézményekben élő része, vagyis a lakosság 99\%-a éppen ezen lakhatási formákban él. Az életszerűség tehát itt vitathatatlan.)

A szabályozás további, rendkívül újszerủ eleme éppen az egyénre szabottságot szolgálja, ugyanis a nagyon pontos diagnózis érdekében a TL igénybevételét megelőzően egy - rendkívül aprólékos, részletes mérőeszközként kifejlesztett - teljeskörü szükségletfelmérés elvégzését írja elő. Az ún. komplex szükségletfelmérés eredményeként - ha szakmailag megfelelően és elfogulatlanul használják a mérőeszközt - pontosan meghatározható, hogy milyen, személyre szabott szolgáltatásokra, szolgáltatási elemekre van szükség az érintett TL-igénybevevőnek.

Ennek kötelezettségét a szabályok szigorú követelményként rögzítik.

- Sztv. 75. §

(6) Támogatott lakhatás - a (7) bekezdés szerinti kivétellel - a komplex szükségletfelmérés, illetve fogyatékos személy esetében a 70 . § (5) bekezdése szerinti alapvizsgálat és a komplex szükségletfelmérés megtörténtét követően, annak eredménye alapján nyújtható.

(7) Ha az ellátott ápolást, gondozást nyújtó intézményből vagy ápológondozó célú lakóotthonból kerül támogatott lakhatásba, az ellátott komplex szükségletfelmérését - folyamatos ellátása mellett - az intézményvezető végzi el. A komplex szükségletfelmérés alapján kell meghatározni az (1) bekezdés $d$ ) pontja szerinti szolgáltatási elemeket, annak eredménye azonban a támogatott lakhatásra való jogosultságot nem érinti.

(7a) Kiskorú ellátása esetén az (1) bekezdés d) pont da) és $d b$ ) alpontja szerinti szolgáltatási elemeket minden esetben biztosítani kell azzal, hogy a felügyelet szolgáltatási elem kizárólag személyes jelenléttel biztosítható.

(8) Ha az ellátott 50 férőhelyesnél nagyobb ápolást, gondozást nyújtó intézményből kerül támogatott lakhatásba, az ápolást, gondozást nyújtó intézmény férőhelyszámát - a támogatott lakhatásba átkerülő ellátottak számával megegyezően - csökkenteni kell.

\section{MiÉRT INNOVATÍV SZOCIÁLIS SZOLGÁL- TATÁS A TÁMOGATOTT LAKHATÁS?}

A címben szereplő kérdést talán akkor a legegyszerübb megválaszolni, ha a TL-t a jóval korábban szabályozásba kerülö lakóotthoni elhelyezéssel vetjük össze.

A törvény ebben a kérdésben egyértelmü: a lakóotthoni ellátás elsősorban ugyanolyan tartós bentlakásos intézményi forma, mint az ápoló-gondozó vagy rehabilitációs célú otthonok. Jelentősebb eltérést a lakhatás mérete jelent (legfeljebb 6-12 fő elhelyezése). 
A TL „mérete” alapvetően hasonló (1-12 fő), de tartalmazza a legfeljebb 50 fős (kvázi társasházi) lakhatás megszervezését is.

A különbség azonban abban áll - és a TL innovatív jellegét ez igazolja -, hogy a lakóotthonban törekedhetnek az önálló életvitel elérésére (opcionális szakmai programelem), és támogathatják az intézményes kötelékek, szabottságok egyes elemeinek szigorát (étkezés, programszervezés stb.). Mindez a TL-ben alapvető követelmény: elsősorban az egyénre szabott, önálló életvitelt mindenképpen biztosító körülmények megteremtése az elvárás, a lakhatás „mérete” már ehhez képest csak technikai-szervezési kérdés (értelemszerüen egy szobatárshoz alkalmazkodni könnyebb feladat, mint több tucat „társasházi lakótárshoz”).

A TL tehát nem pusztán egy új szervezési, szervezeti forma, nem egy újabb szolgáltatás az amúgy is elég széles palettán. A TL egy új szemléletet, egy új paradigmát kínál: minden érintett - értelmi vagy pszichoszociális fogyatékossággal élö, szenvedélybeteg - ellátott a legnagyobb önállóság mellett, saját személyére szabott és rugalmasan módosítható támogatás segítségével élhesse életét. És ez a müködési módszer megegyezik valamennyi - korábban sorolt szabályozásokban, egyezményekben meglévő - elvárással, az érintettek és képviselőik igényeivel.

\section{A tÁMOGATOTT LAKHATÁS JÖVŐKÉPE}

A TL megszületése és kialakított feltételrendszere alapján, ismerve azt a tényt is, hogy kevés szolgáltatások egyike, ahol nincs állami befogadási kötelezettség, úgy is tűnhet, hogy ez lehet a fordulat a fogyatékossággal élő személyek életében. A jövőt a választhatóság, a szükségletközpontúság és a rugalmasság jellemzi majd.

Jelenleg azonban még „nem áll” győzelemre a TL. Egyrészt azért, mert teljes mértékben elmaradni látszanak a helyi szolgáltatásfejlesztések. Bár - elsősorban az állami intézményfenntartó - rendkívül sok forrást költhetett eddig is a rendszer átalakítására, mégsem történt meg az igénybevehető, otthonközeli, fogyatékosok számára specializált szolgáltatások bővülése. Olyannyira nem, hogy a 2016 előtt, EU-s forrásból létrejött TL-ekben kifejlesztett szolgáltatások külső igénybevétele gyakorlatilag nulla volt. Ez azt jelenti, hogy a kialakított alapszolgáltatások kizárólag a nagy (esetleg teljesen kitagolt) intézményből kikerült lakók számára voltak igénybevehetők. Sem a településen, sem a környéken élő személyek és családok számára nem nőtt az alapellátás elérhetősége. A TL elindításának a legtöbbször semmiféle hatása nem volt az érintett települések alapvető szolgáltatói környezetére. Így azonban a szükséges és változásokat ténylegesen elérni képes szolgáltatási bővülés nem valósul meg.

Másrészt már az is látható, hogy a „lakócentrumok” szabályai, az 50 fős ellátásszervezési szintig szinte automatikusan „visszaintézményesednek”. Hiába a megannyi hozzáadott érték, tudás, szemléletformálás, a szolgáltatás szereplői egyre inkább „miniintézményként” működtetik ezeket a helyeket. Ez pedig - látva, hogy a kitagolási programban továbbra is csak állami szereplő vesz részt - elörevetíti a szemléletváltás, az új paradigma lassú elhalását, bizonyos szempontól a visszafordulását.

Részletkérdésnek tünik, de nagyon fontos lenne - szakmai és ellátottjogi oldalról - lefolytatni azokat a vitákat is, amely a középsúlyos, súlyos és halmozottan fogya- 
tékos személyek, egyes - ön- és közveszélyes eseteket is felmutatni tudó - pszichiátriai kórképpel élők vagy súlyos szenvedélybetegségben szenvedők eseteit külön megvizsgálná. Ezek a viták feltehetnék - és jó esetben megválaszolhatnák - azt a kérdést, hogy az ellátási biztonság oltárán (különösen magas ápolási-gondozási szükséglet, 0-24 órás felügyeleti igény esetén) mi minden áldozható fel a - sokszor rosszul értelmezett - emberi jogi elvárások érdekében. Hol van az ésszerü megoldás az erőforrás-korlátok, ellátási biztonság és szabadságjogok értelmezési keretében? Ezekbe a disputákba pedig jó lenne minden érintettet bevonni és széles konszenzust teremteni - nehogy végleg elvesszen a TL nyújtotta előny és előrelépés.

A TL bevezetése, szakmailag helyes müködtetése azonban még így is egy fontos lépés lehet az önálló életvitel felé, a nagy létszámú intézmények lebontásának céljából. Ezzel egyúttal, túlzások nélkül állítható, hogy az utóbbi évtized legfontosabb szociális szolgáltatási innovációjává vált a TL. Ideje lenne azonban már a továbblépésnek és a szemléletváltás megerösítésének.
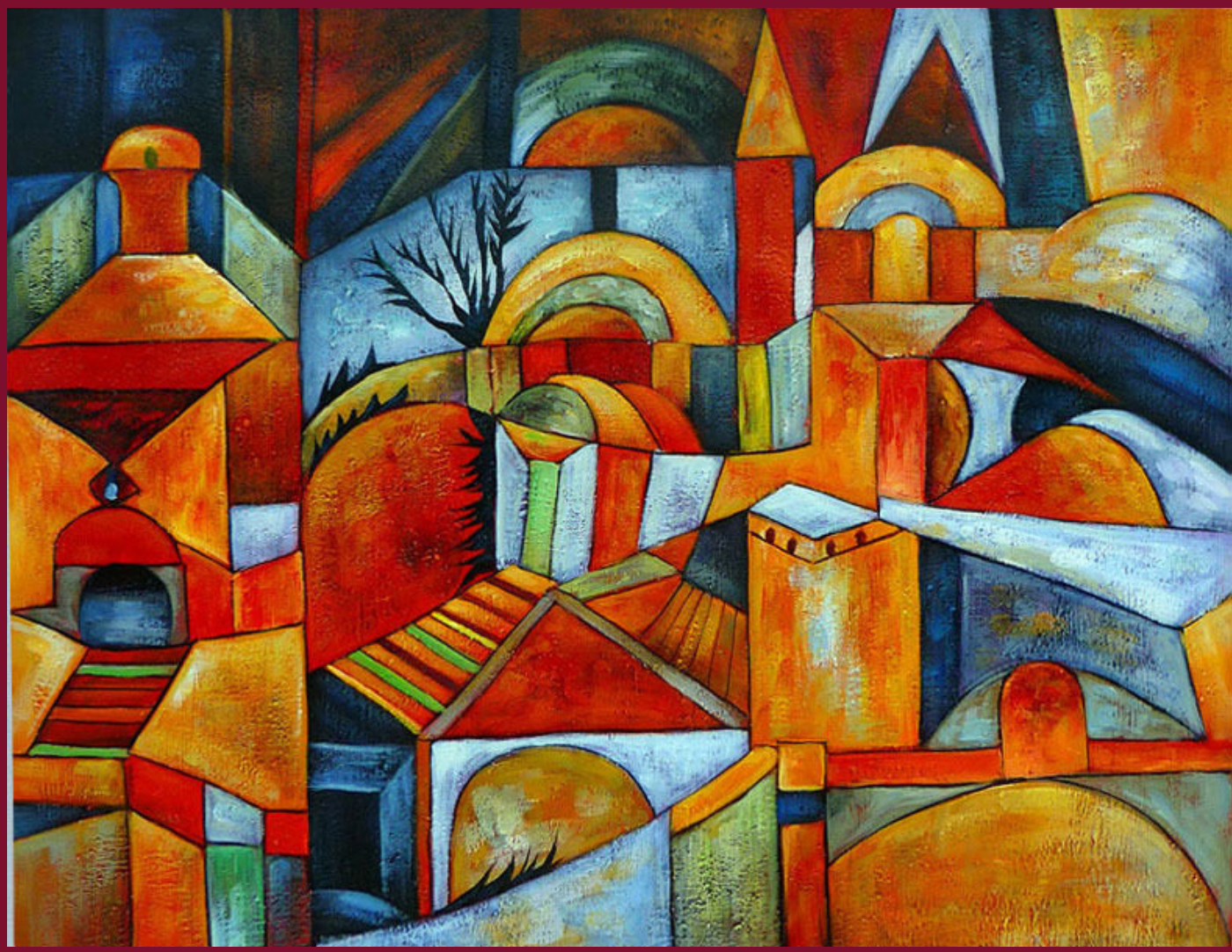